\title{
A Study on Alternative Approaches to Instill Environmental Concerns in the Domain of Production Management of Industrial Firms
}

\author{
Ronaldo Manzan', Dario Ikuo Miyake²
}

\begin{abstract}
This article presents a comparative analysis of alternative models of production with environmental concerns that may lead to higher effectiveness in initiatives undertaken by industrial firms towards the development of more sustainable operations. The objective is to organize the knowledge on the subject of such models and provide guidelines that may help managers in selecting the most fitting approach for their business, according to the strategy and conditions of the firm. Among the presented models, the Cleaner Production model stands out for promoting the approach of nurturing the concurrent strengthening of quality, productivity, and sustainability in the existing manufacturing processes by dealing more comprehensively with factors internal to the firm that may be directly controlled by the managers.
\end{abstract}

Keywords: cleaner production; environmental performance; production management; productivity; sustainability

\footnotetext{
'University of Sao Paulo, Graduate Program in Production Engineering, Av. Prof. Almeida Prado trav. 2, n. I28, Cidade Universitária, 05508070, São Paulo, SP, Brazil. Phone: +55-I I-99975-6504. E-mail: ronaldomanzan I @hotmail.com

${ }^{2}$ University of Sao Paulo, Polytechnic School, Department of Production Engineering, Av. Prof. Almeida Prado trav. 2, n. I28, Cidade Universitária, 05508-070, São Paulo, SP, Brazil. Phone: +55-I I-309I-5363. E-mail: dariomiy@usp.br
}

ISSN: 07 I8-2724. (http://www.jotmi.org)

Journal of Technology Management \& Innovation (c) Universidad Alberto Hurtado, Facultad de Economía y Negocios. 


\section{Introduction}

The United Nations Environmental Program (UNEP) was created on December 15th, 1972 by a resolution of the United Nations General Assembly (n. 2997 - XXVII), but only 20 years later, in 1992, this program was actually adopted in the United Nations Conference on Environment and Development, called as Agenda 21 (Sitarz, 1993), during the Earth Summit held in Rio de Janeiro (Brazil). Despite these actions, during the Millennium Summit held in year 2.000 in Malmö (Sweden), the UN Secretary-General's reported concerns that the challenges of sustainable development simply overwhelmed the effectiveness of our responses and that with some honorable exceptions, our responses were too few, too little and too slow. Now, after about 40 years since that UN's General Assembly resolution was established, many concerns on sustainable development remain almost in the same position; as key drivers like the actions towards environmental protection that should be deployed by government, technology developers and individual firms are not advancing as expected.

In manufacturing industry, a major consumer of natural resources and source of pollution, reliable guidelines and parameters for environment control have already been defined. The ISO 14000 standards for environmental management systems introduced in 1996 constitute a relevant instrument to promote them. A growing number of firms worldwide have exploited the certification by these standards as a means to promote and reinforce their approach to environmental management, however, in a slower pace if compared to the search of ISO 9000 certifications for the quality management system, as exhibited in Figure I.

The United Nations Industrial Development Organization (UNIDO) believes that competitive and environmentally sustainable industries have a crucial role to play in accelerating economic growth, reducing poverty and thus achieve the so called Millennium Development Goals (United Nations, 2005), which primarily were targeted to be accomplished until 2015. The economic development brings benefits, but on the other hand, it has also been largely responsible for the degradation of the environment and has caused damages that deteriorate the quality of life. Investors, managers, engineers and researchers concerned with manufacturing firms and production systems have crucial roles in the promotion of industrial development with environment protection, to ensure the sustainability of the planet for future generations. Production models with environmental concerns

Since the establishment of a fundamental policy for sustainable industrial development by $\mathrm{UN}$, a number of approaches were developed and proposed by different organizations to serve as a means to minimize the environmental impact caused by the production system of industrial firms. Based on a literature review of works that consider the propositions of such initiatives and their implementation, the five approaches listed below were identified as those that have been most influential:

- Adoption of End-of-Pipe technologies for pollution control; - Cleaner Production;

- Green Production or Green Manufacturing;

- Sustainable Production;

- Sustainable Production and Consumption.

The following sections present each of them pointing out their main features.

\section{Adoption of End-of-Pipe Technologies}

The adoption of End-of-Pipe technologies is a classical contrivance for pollution control based on devices normally implemented in latter stages of a manufacturing process. They are not part of the production process, but accessories used to mitigate the deleterious effects of emissions generated

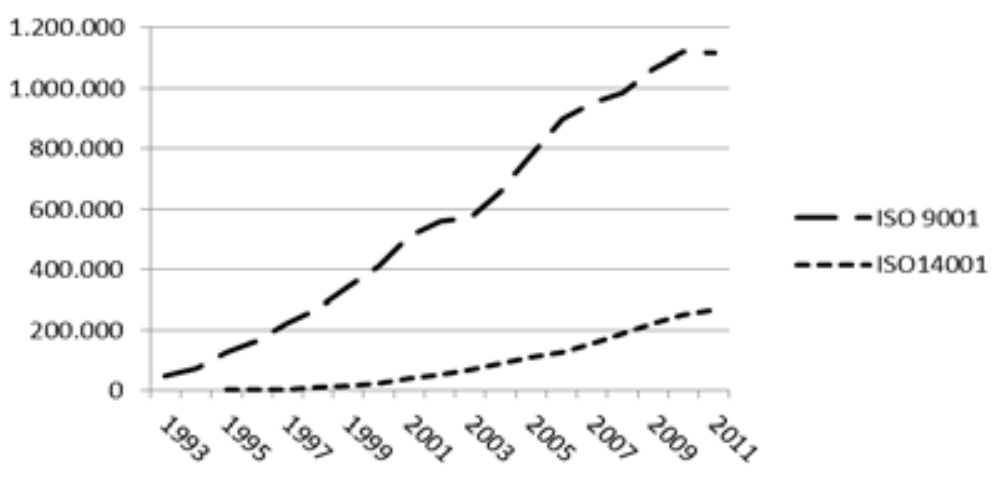

Figure I: ISO 900 I e ISO I400 I certifications in the world, from 1993 to 201 I. Data from: ISO Survey <http://www.iso.org/iso/home/ standards/certification/iso-survey.htm> [Accessed February 19, 20I3]

ISSN: 07 I8-2724. (http://www.jotmi.org)

Journal of Technology Management \& Innovation (c) Universidad Alberto Hurtado, Facultad de Economía y Negocios. 
by the production process. The environmental concern of this model is focused in the control of pollution generation and implies a kind of investment made in industrial plants that does not bring a definitive improvement of the production process in terms of lower emission generation. Furthermore, even if investments are made in the installation of End-of-Pipe technologies, the lack of a sound management system for environmental control may not result in a better environmental performance (Berkel, Willems and Lafleur, 1997; Rothenberg, Pil and Maxwell, 200 I). For example, Hillary and Thorsen (1999) found actions to mitigate water pollution that still had environmental problems due to the deposition of sludge in a landfill, only changing the place of the problem and not solving it definitely.

End-of-Pipe Technologies are the most common approach adopted by the firms because they are of faster and easier implementation, not demanding radical changes in the established management structure. However, End-of-Pipe actions involve much specific technology and still demand considerable investments. This is one of the reasons that could explain why the pace of implementation of environmental protection initiatives have been so slow, as only a small portion of the firms can afford to bear that cost (Moors, Mulder and Vergragt, 2005; Frondel, Horbach and Rennings, 2007). According to Pailthorp (1977), to bring about more effective benefits for the firm, these type of investments should be better planned to allow recycle or re-use of wastes.

\section{Cleaner Production (CP)}

The concepts of CP, as conceived by UNEP, constitute a model of production that causes less environmental impacts that should be pursued by industrial organizations through the deployment a set of new practices based on the principles listed in Table I, which are highlighted by authors like Fresner (1998) and Berkel;Willems and Lafleur (1997).

I. GOOD HOUSEKEEPING: appropriate provisions to prevent leaks and spills and to achieve proper, standardized operation and maintenance procedures and practices; 2. INPUT MATERIAL CHANGE: replacement of hazardous or non-renewable inputs by less hazardous or renewable materials or by materials with a longer service lifetime;

3. BETTER PROCESS CONTROL: modification of the working procedures, machine instructions and process record keeping for operating the processes at higher efficiency and lower rates of waste and emission generation;

4. EQUIPMENT MODIFICATION: modification of the production equipment so as to run the processes at higher efficiency and lower rates of waste and emission generation;

5. TECHNOLOGY CHANGE: replacement of the technology, processing sequence and/or synthesis pathway in order to minimize the rates of waste and emission generation during production;

1. GoOD HouSEKEEPING: appropriate provisions to prevent leaks and spills and to achieve proper, standardized operation and maintenance procedures and practices;

2. InPut Material Change: replacement of hazardous or non-renewable inputs by less hazardous or renewable materials or by materials with a longer service life-time;

3. Better Process Control: modification of the working procedures, machine instructions and process record keeping for operating the processes at higher efficiency and lower rates of waste and emission generation;

4. EQUipment Modification: modification of the production equipment so as to run the processes at higher efficiency and lower rates of waste and emission generation;

5. Technology Change: replacement of the technology, processing sequence and/or synthesis pathway in order to minimize the rates of waste and emission generation during production;

6. On-Site ReCovery/Reuse: reuse of the wasted materials in the same process or for another useful application within the company;

7. Production of Useful By-Products: transformation of previously discarded wastes into materials that can be reused or recycled for another application outside the company; and

8. Product Modification: modification of product characteristics in order to minimize the environmental impacts of the product during or after its use (disposal) or to minimize the environmental impacts of its production.

Table I: Cleaner Production basic principles.

ISSN: 07I 8-2724. (http://www.jotmi.org)

Journal of Technology Management \& Innovation (c) Universidad Alberto Hurtado, Facultad de Economía y Negocios. 
6. ON-SITE RECOVERY/REUSE: reuse of the wasted materials in the same process or for another useful application within the company;

7. PRODUCTION OF USEFUL BY-PRODUCTS: transformation of previously discarded wastes into materials that can be reused or recycled for another application outside the company; and

8. PRODUCT MODIFICATION: modification of product characteristics in order to minimize the environmental impacts of the product during or after its use (disposal) or to minimize the environmental impacts of its production.

Since 1994, UNEP and UNIDO have worked cooperatively in an international program to foster the implementation of National Cleaner Production Centres (NCPC) as a mechanism to deliver value-added services of Cleaner Production for enterprises, governmental agencies and other organizations (Luken and Navratil, 2004).As of February 20 I2, a total of 54 NCPCs were already in operation in 47 countries, organized to promote the dissemination of $\mathrm{CP}$ concepts and practices in industries.

The CP model is considered as an approach based on a set of more preventive techniques to achieve environmental benefits (Berkel, Willems and Lafleur, 1997). Thus, the application of its concepts and techniques in the earlier stages of the production process would make the effort of reducing environment impacts more efficient. The results of their implementation in later stages of the production process tend to be more limited either in terms of resource saving or in terms of emission reduction. Several articles that present case studies on implementation of CP have found that the main motivation for adopting this approach has been the need to reduce pollution at a lower cost (Fresner, 1998; Moors, Mulder and Vergragt, 2005; Frondel, Horbach and Rennings, 2007). The issues of process rationalization and of reduction of natural resources consumption are also contemplated in the $\mathrm{CP}$ approach, but only either as a consequence or as a secondary objective in the search of environmental efficiency.

\section{Green Manufacturing}

The expression "green manufacturing" can be found in many articles concerning the issue of developing more sustainable manufacturing systems published in the United States, where it was introduced, but it has also been disseminated in some other countries as China. The concept of "green" entails a broader proposal of promoting a greener living, thus it has been adopted by the United States Environmental Protection Agency (US-EPA) to highlight this attribute of embracing all activities developed with a focus on sustainability. To promote the development of greener manufacturing pro- cesses, manufacturing firms should abide by a number of requirements like accounting of wastes, accomplishment of environmental laws, and building a green culture with the involvement of the workers (Atlas and Florida, 1998; Dickinson et al., 1995). The emphasis of the green manufacturing approach is put on the production process, targeting higher efficiency. Regarding this point, these authors firmly defend the implementation of a greater degree of process automation and more continuous production processes. According to Rothenberg, Pil and Maxwell (200I), continuous process could be better than batch process because it avoids cleaning and machine set-up operations required by each batch.

It is worth noting that the term "green production" may be used in an equivalent manner by authors like Hart (1994), who discussed the adoption of green production as a more evolved production paradigm to replace the lean production strategy in the American auto industry.

\section{Sustainable Production}

The idea of pursuing sustainable production systems has been increasingly discussed by various agents of the society engaged in the development of more sustainable practices in general and was introduced by an article written by Repetto (1987) about the economic benefits that a sustainable production could bring for agriculture. A more formal approach to Sustainable Production is the one proposed by the Lowell Center for Sustainable Production (LCSP) of Lowell University at Massachusetts (Veleva et al., 200I; Edwards, 2009), after the development of a pilot project for an industry in 1995. According to this organization, Sustainable Production is the creation of goods and services using processes and systems that are:

$$
\begin{aligned}
& \text { - Non-polluting, } \\
& \text { - } \quad \text { Conserving of energy and natural resources, } \\
& \text { Economically viable, } \\
& \text { consumers, } \\
& \text { - Sand healthful for workers, communities, and } \\
& \text { people. }
\end{aligned}
$$

Veleva and Ellenbecker (200I) present indicators for sustainable production developed by the LCSP.These indicators are based on ten principles that stimulate the pursuit for productivity and efficiency by the enterprises, reducing costs and increasing results for the business as a whole. The scope considered by this proposal of Sustainable Production is broader in comparison to the approaches discussed in previous sections. It involves the production of goods and services, and, besides impacts on environment, is also concerned with the working environment and social responsibility. 


\section{Sustainable Production and Consumption (SPC)}

The SPC approach emerged as a means to integrate the objectives of the CP with the principles of Responsible Consumption. Several entities use its concepts as an extension of the CP model aiming, not only the improvement of production processes and their better control, but the rationalization of consumption patterns. Due to the commitment to sustainable development that was reaffirmed in the Earth Summit on Sustainable Development held in Johannesburg in 2002, UNEP defined an agenda for further meetings and periodic reviews to check the progress of the devised actions. As a part of this movement, in 2003, a comprehensive program for a ten years period (IOYFP - ten years framework program) known as the Marrakesh Process (Clark, 2007) was established, with a series of initiatives to promote the achievement of reasonable patterns for sustainable production and consumption, aligned to the needs of economic and social development, within the limits of the ecosystems capacity.

In comparison to the approaches presented in previous sections, SPC reveals a much wider scope. The principles of CP for example are to a great extent contemplated in the actions nurtured by SPC. The first article about SPC found in the Web of Knowledge database was published by Mulder (1998). This article is about sustainability in the plastics industry and, in face of its great environmental impacts, discusses the future viability of this industry through changes in production and consumption patterns.

\section{Comparative analysis of alternative production models with environmental concerns}

An overview of the five models considered in this article in terms of origin, year of creation and basic guidelines is presented in Table 2. It suggests that the evolution of production models with environmental concerns started from the idea of mitigating the pollution effects caused by the production process, and then evolved to encompass changes in the production process aiming the saving of natural resources and use of less toxic substances. Nevertheless, as the accomplishment of results by means of such actions has been too slow, the models conceived more recently have incorporated guidelines to encourage changes in the consumption patterns of the society in a more proactive way.

The analysis of the set of production models with environmental concerns considered in this article revealed that, in a general way, as outlined in Figure 2, their proposals and prescriptions for designing and operating eco-friendly production systems share a similar structure comprising the following three fundamental components:

- $\quad$ Fundamental principles and concepts,

- Design of products and manufacturing processes with lower environmental impacts, and

- Management practices and production rationalization mechanisms.

\begin{tabular}{|c|c|c|c|c|c|}
\hline Model & $\begin{array}{l}\text { END-OF-PIPE } \\
\text { TECHNOLOGY }\end{array}$ & $\begin{array}{c}\text { CLEANER } \\
\text { PRODUCTION }\end{array}$ & $\begin{array}{c}\text { GREEN } \\
\text { MANUFACTURING }\end{array}$ & $\begin{array}{l}\text { SUSTAINABLE } \\
\text { PRODUCTION }\end{array}$ & $\begin{array}{c}\text { SUSTAINABLE } \\
\text { PRODUCTIONAND } \\
\text { CONSUMPTION }\end{array}$ \\
\hline $\begin{array}{c}\text { Origin / } \\
\text { Proponent }\end{array}$ & $\begin{array}{c}\text { Developers of } \\
\text { pollution control } \\
\text { tools }\end{array}$ & UNIDO - UNEP & US-EPA & $\begin{array}{c}\text { University of } \\
\text { Massachusetts } \\
\text { Lowell }\end{array}$ & $\begin{array}{l}\text { UNEP -Mar- } \\
\text { rakesh Process }\end{array}$ \\
\hline $\begin{array}{c}\text { Year of } \\
\text { establishment }\end{array}$ & 1977 & 1991 & $1994 / 95$ & $1995 / 96$ & $1996 / 2002$ \\
\hline $\begin{array}{c}\text { Focus / } \\
\text { Emphasis }\end{array}$ & $\begin{array}{l}\text { Mitigation of the } \\
\text { production pro- } \\
\text { cess waste effects } \\
\text { on the environ- } \\
\text { ment }\end{array}$ & $\begin{array}{l}\text { Integrative strat- } \\
\text { egy for environ- } \\
\text { mental protection } \\
\text { to increase effi- } \\
\text { ciency of produc- } \\
\text { tion process and } \\
\text { reduce damages } \\
\text { to men and envi- } \\
\text { ronment }\end{array}$ & $\begin{array}{l}\text { Environment } \\
\text { protection cul- } \\
\text { ture promoted } \\
\text { by regulations, } \\
\text { top management } \\
\text { and workers' } \\
\text { participation, } \\
\text { and reduction } \\
\text { of waste cost } \\
\text { through cleaner } \\
\text { production }\end{array}$ & $\begin{array}{l}\text { Non-polluting } \\
\text { production } \\
\text { process that } \\
\text { conserve ener- } \\
\text { gy and are safe } \\
\text { for workers, in } \\
\text { accordance with } \\
\text { societal expecta- } \\
\text { tions }\end{array}$ & $\begin{array}{c}\text { Promotion of } \\
\text { sustainable } \\
\text { production } \\
\text { patterns, along } \\
\text { with social and } \\
\text { economic devel- } \\
\text { opment }\end{array}$ \\
\hline
\end{tabular}

Table 2: Evolution of production models with environmental concerns

ISSN: 07I 8-2724. (http://www.jotmi.org)

Journal of Technology Management \& Innovation (c) Universidad Alberto Hurtado, Facultad de Economía y Negocios. 
These production models propose the development of industrial systems that enable production while minimizing environmental impact. To seek this goal, they establish a set of fundamental concepts and principles to guide the decisions and actions in the planning, design and installation of new plants or in the retrofitting of plants already in operation. Table 3 presents a more detailed description of the fundamental principles and concepts advocated by each model.All these models have as their primary goal the improvement of the firm's environmental performance and, with the exception of the approach of adopting End-of-Pipe technologies, they reveal keen concerns to support the industries in their strive to reduce production costs and to seek the long-term viability of their business, in terms of both environmental and economic aspects. However, only two of the considered models, namely Green Manufacturing and SPC, explicitly highlight the need to include the environmental concerns in the strategic planning of the enterprise.

Both Green Manufacturing and End-of-Pipe Technologies do not emphasize issues like the improvement of the inner environment of the plants and the improvement of workers' safety and health conditions. These models are more inclined to cope with the problem of controlling the pollution that industrial activities emit to the outside environment. Moreover, these two models also do not comprise principles to enhance control over the supply chain, issues related to the social responsibility of the enterprise, and the promotion of changes in consumption pattern.

As a matter of fact, the latter issues are not emphasized by the first production models with environmental concerns

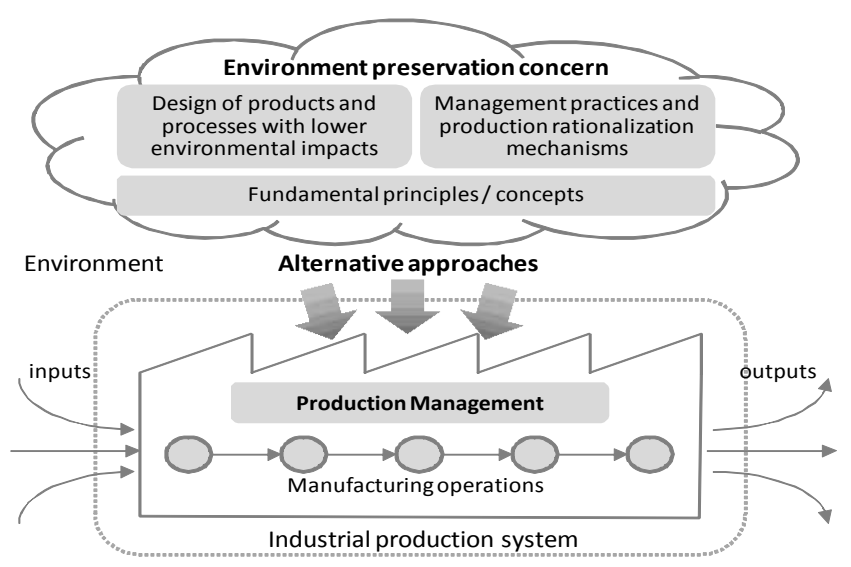

Figure 2:The domain of production planning and the structure of production models with environmental concerns which are rather constrained to the promotion of control measures and technology changes within the inner context of manufacturing plants. The environment preservation initiatives involving agents external to a plant or a firm were only embraced more recently with the advent of Sustainable Production and SPC models with the motivation of seeking more effective and lasting results.

As for the elements related to the design of products and manufacturing processes proposed by the considered models, they are presented in Table 4. A clear difference can be noted in the focus of Sustainable Production and Green Manufacturing. While the former emphasizes the need of a new orientation for the design of products and packages reconciling sustainability issues, the latter is focused in actions directed to changes in manufacturing processes in a way to assure the environmental and economic efficiency of the industry. With regard to CP and SPC, these models are more comprehensive and look for results improving the design of products and packages as well as of manufacturing processes and resources. On the other hand, the adoption of End-of-Pipe technologies does not comprise any element related to the design of products and processes because it is rather concerned with the consequences "outside the plant" advocating actions intended to mitigate the negative effects of the emissions caused by the production process.

Finally, Table 5 compares the production models in terms of management practices and production rationalization techniques they advocate to reduce environmental impacts. As for this component, the adoption of End-of-Pipe technologies is essentially aimed at pollution control and compliance to requirements of governmental regulations that implicate the implementation of remedial devices, which frequently rely on sophisticated and costly technologies. Their adoption is heavily dependent on governmental actions. Among the models considered, this is the only one that does not include actions intended to revise conditions under which the production process takes place in earlier stages and the current practices of operations management.

Clear gaps are also found in other production models. The Green Manufacturing model for instance reveals a clear focus on the enhancement of production process efficiency, but it does not draw attention to the examination of what kind of product or by-product is being produced, and of what kind of materials they require so as to minimize the environmental impacts they may be causing. In general, the models analyzed in this article are devised not only to instill environmental concerns and targets in the domain of production management of industrial firms, but also to be more instrumental by proposing the application of a combination of techniques and practices intended to foster the development of sustainable industrial production. 


\section{Final considerations}

Production Management, either as a relevant discipline in areas like Engineering and Business Administration or as a key function in industrial firms, now faces the challenge of reviewing its own role, premises, body of knowledge, and scope of related competences in order to drive the incorporation of sustainability requirements in the definition of the ultimate goals of industrial operations. Kleindorfer, Singhal and Wassenhove (2005) presented a review of the articles published in 50 editions (from I99I to 2004) of the Production and Operations Management (POM) journal in which they identified a growing concern to promote the integration of many elements of Production Management with sustainability-oriented elements. This suggests that the idea of exploring connections between the application of production planning and management tools in search of not only productivity and profitability, but also of sustainability, is drawing increasing attention stimulating the debate and further research on this promising path. However, there are some specific attributes that justify the adoption of a given model depending on the goals and needs of each firm. From the consideration of these models that propose actions to reconcile industrial development and rational use of the available resources, a framework comprising their essential elements could be established.

If we consider more specifically the policies and actions that could be driven and deployed under the domain of Production Management, the approaches that are more directly

\begin{tabular}{|l|c|c|c|c|c|}
\hline \multicolumn{1}{|c|}{ Model } & $\begin{array}{c}\text { ENDOF-PIPE } \\
\text { TECHNOLOGY }\end{array}$ & $\begin{array}{c}\text { CLEANERPRO- } \\
\text { DUCTION }\end{array}$ & $\begin{array}{c}\text { GREEN MANU- } \\
\text { FACTURING }\end{array}$ & $\begin{array}{c}\text { SUSTAINABLE } \\
\text { PRODUCTION }\end{array}$ & $\begin{array}{c}\text { SUSTAINABLEPRODUCTION } \\
\text { ANDCONSUMPTION }\end{array}$ \\
\hline $\begin{array}{l}\text { Improvement of environmen- } \\
\text { tal performance }\end{array}$ & $\checkmark$ & $\checkmark$ & $\checkmark$ & $\checkmark$ & $\checkmark$ \\
\hline Production cost reduction & & $\checkmark$ & $\checkmark$ & $\checkmark$ & $\checkmark$ \\
\hline $\begin{array}{l}\text { Long-term viability of the } \\
\text { enterprise }\end{array}$ & & $\checkmark$ & $\checkmark$ & $\checkmark$ & $\checkmark$ \\
\hline $\begin{array}{l}\text { Environmental issues as a part } \\
\text { of the firm's strategy }\end{array}$ & & & $\checkmark$ & & $\checkmark$ \\
\hline $\begin{array}{l}\text { Rewarding of the workers } \\
\text { creativity }\end{array}$ & & & & $\checkmark$ & \\
\hline $\begin{array}{l}\text { Promotion of safety and } \\
\text { healthiness of the workers }\end{array}$ & & & & $\checkmark$ & \\
\hline $\begin{array}{l}\text { Economic, social and cultural } \\
\text { interaction with the } \\
\text { community }\end{array}$ & & & & $\checkmark$ & $\checkmark$ \\
\hline $\begin{array}{l}\text { Cooperative relations with the } \\
\text { supply chain }\end{array}$ & & & & & $\checkmark$ \\
\hline Change of consumer habits & & & & \\
\hline
\end{tabular}

Table 3: Fundamental principles and concepts of the production models with environmental concerns

\begin{tabular}{|l|c|c|c|c|c|}
\hline \multicolumn{1}{|c|}{ Model } & $\begin{array}{c}\text { ENDOF-PIPETECH } \\
\text { NOLOGY }\end{array}$ & $\begin{array}{c}\text { CLEANER PRO- } \\
\text { DUCTION }\end{array}$ & $\begin{array}{c}\text { GREENMANUFAC- } \\
\text { TURING }\end{array}$ & $\begin{array}{c}\text { SUSTAINABIE } \\
\text { PRODUCTION }\end{array}$ & $\begin{array}{c}\text { SUSTAINABLEPRODUCTION } \\
\text { ANDCONSUMPTION }\end{array}$ \\
\hline Product changes & $\checkmark$ & & $\checkmark$ & $\checkmark$ \\
\hline Package changes & & $\checkmark$ & & $\checkmark$ & \\
\hline $\begin{array}{l}\text { Increase of } \\
\text { mechanization }\end{array}$ & & $\checkmark$ & $\checkmark$ & & $\checkmark$ \\
\hline $\begin{array}{l}\text { Equipment } \\
\text { changes }\end{array}$ & & $\checkmark$ & $\checkmark$ & & $\checkmark$ \\
\hline Process changes & & $\checkmark$ & $\checkmark$ & & $\checkmark$ \\
\hline
\end{tabular}

Table 4: Elements related to the design of products and manufacturing processes advocated by production models with environmental concerns

ISSN: 07 I8-2724. (http://www.jotmi.org) 
concerned with it are those advocated by the End-of-Pipe, $\mathrm{CP}$ and Green Manufacturing models. It is worth mentioning that $\mathrm{CP}$ in particular was highlighted by Robèrt et al. (2002) as an approach that is geared more specifically to the field of industrial manufacturing. Among the models considered in this article, as presented by Table 5, CP is the model that cares more comprehensively with the various aspects of manufacturing systems, comprising a greater number of elements of management practices and production rationalization mechanisms. This model is concerned with both products and by-products, nurtures process improvements to enhance the performance of both the economic and environmental dimensions of manufacturing operations, promotes the improvement of environmental conditions at the production site, and cares for the workers' health and safety conditions.

It is a model that proposes in a more objective way, rationalization mechanisms for industrial activities with the ration- ale of saving natural resources and preserving the environment, whereas other models like Sustainable Production and SPC advocate actions that go beyond the boundaries of a manufacturing plant and may involve external agents like other firms in the supply-chain, the community close to the focal firm, the government, and even the society (i.e. the consumers). The interventions or changes advocated by these models in such areas outside the bounds of industrial plants, although relevant and indispensable, far surpass the domain of production managers and depend crucially on external factors like governmental policies or cultural changes in the society.

Finally, it is necessary to consider that the decision of which approach to adopt as the primary reference model to reconcile Production Management with environmental preservation measures may also be influenced by forces external to the organization. Authors such as Dong et al. (2010) point out that among the alternatives of implementing $\mathrm{CP}$ prac-

\begin{tabular}{|c|c|c|c|c|c|}
\hline Model & $\begin{array}{l}\text { ENDOF-PIPE } \\
\text { TECHNOLOGY }\end{array}$ & \begin{tabular}{|c|} 
CLEANERPRODUC- \\
TION
\end{tabular} & $\begin{array}{l}\text { GREENMANUFAC- } \\
\text { TURING }\end{array}$ & $\begin{array}{l}\text { SUSTAINABLE } \\
\text { PRODUCTION }\end{array}$ & $\begin{array}{l}\text { SUSTAINABLEPRODUCTION } \\
\text { ANDCONSUMPTION }\end{array}$ \\
\hline $\begin{array}{l}\text { Mitigation of pollution } \\
\text { effects }\end{array}$ & $\checkmark$ & & & & \\
\hline $\begin{array}{l}\text { Accomplishment of mini- } \\
\text { mum legal patterns }\end{array}$ & $\checkmark$ & & $\checkmark$ & & $\checkmark$ \\
\hline $\begin{array}{l}\text { Search of governmental } \\
\text { program subsidies }\end{array}$ & $\checkmark$ & & $\checkmark$ & & $\checkmark$ \\
\hline $\begin{array}{l}\text { Development of new } \\
\text { product and process tech- } \\
\text { nologies }\end{array}$ & $\checkmark$ & $\checkmark$ & & & $\checkmark$ \\
\hline $\begin{array}{l}\text { Rationalization oriented } \\
\text { production management }\end{array}$ & & $\checkmark$ & $\checkmark$ & $\checkmark$ & $\checkmark$ \\
\hline $\begin{array}{l}\text { Continuous training of } \\
\text { workers }\end{array}$ & & $\checkmark$ & $\checkmark$ & $\checkmark$ & $\checkmark$ \\
\hline Energy saving & & $\checkmark$ & $\checkmark$ & $\checkmark$ & $\checkmark$ \\
\hline Raw material saving & & $\checkmark$ & $\checkmark$ & $\checkmark$ & $\checkmark$ \\
\hline $\begin{array}{l}\text { On-site recovery and } \\
\text { reuse }\end{array}$ & & $\checkmark$ & & & \\
\hline $\begin{array}{l}\text { Production of useful } \\
\text { by-products }\end{array}$ & & $\checkmark$ & & & \\
\hline $\begin{array}{l}\text { Elimination of hazardous } \\
\text { products }\end{array}$ & & $\checkmark$ & & $\checkmark$ & $\checkmark$ \\
\hline Process control & & $\checkmark$ & $\checkmark$ & & $\checkmark$ \\
\hline $\begin{array}{l}\text { Changes for safer and } \\
\text { healthier work place }\end{array}$ & & $\checkmark$ & & $\checkmark$ & \\
\hline $\begin{array}{l}\text { Continuous process man- } \\
\text { ufacturing }\end{array}$ & & & $\checkmark$ & & \\
\hline
\end{tabular}

Table 5: Management practices and production rationalization mechanisms advocated by production models with environmental concerns

ISSN: 07 I8-2724. (http://www.jotmi.org) 
tices or adopting End-of-Pipe technologies, governmental subsidy and penalty policies, for example, can stimulate the choice of the first approach since such policies may augment the cost difference between these alternatives. Governmental programs to improve consumer education should also be complemented with incentives for the industries to adopt $\mathrm{CP}$ practices. When consumers more aware of sustainability issues have the option to make a choice among different product suppliers that have, or do not have, an environmental concern, the power of the market and society tend to induce more suppliers to adopt the CP concepts and methods in their manufacturing process. In this context, the adoption of $\mathrm{CP}$ can potentially bring a full range of advantages to the adherent firms: improved results in terms of economic performance (by cost reduction), enhanced environmental performance (by pollution reduction), and superior marketing performance (by building a more positive corporate image that drive an increase of the marketing share).

\section{References}

ATLAS, M.; Florida, R. (1998). Green Manufacturing; In DORF, R. (ed.) Handbook of Technology Management. CRC Press.

BERKEL, R. van;Willems, E.; Lafleur, M. (1997). The relationship between cleaner production and industrial ecology; Journal of Industrial Ecology, I (I).

CLARK, G. (2007). Evolution of the global sustainable consumption and production policy and the United Nations Environment Programme's (UNEP) supporting activities. Journal of Cleaner Production. I5(6), 492-498.

DICKINSON, D.A.; Draper, C.W.; Saminathan, M.; Sohn, J.E.; Wiliams, G. (1995). Green Product Manufacturing. AT\&T Technical Journal, 74(6), 26-35.

DONG, X.; Li, C.; Li, J.; Wang, J.; Huang, W. (20I0). A gametheoretic analysis of implementation of cleaner production policies in the Chinese electroplating industry. Resources, Conservation and Recycling, 54(I2), I 442-I 448.

EDWARDS, S. (2009). A new way of thinking: the Lowell Center framework for sustainable products. Lowell Center for Sustainable Production, University of Massachusetts Lowell, Lowell, MA.

FRESNER, J. (1998). Cleaner Production as a means for effective environment management. Journal of Cleaner Production, 6(3-4), 17I-I79.

FRONDEL, M.; Horbach, J.; Rennings, K. (2007). End-of-pipe or Cleaner Production? An empirical comparison of environmental innovation decisions across OECD countries. Business, Strategy and the Environment. 16(8), 57I-584.

HART, S.L. (1994). How green production might sustain the world. Journal for the Northwest Environment. I0(I), 4-I4.

HILLARY, R.; Thorsen, N. (1999). Regulatory and self-regulatory measures as routes to promote cleaner production. Journal of Cleaner Production. 7(I), I-I I.

KLEINDORFER, P.R.; Singhal, K.; Wassenhove, L.N. van (2005). Sustainable Operations Management. Production and Operations Management, I4(4), 482-492.

LUKEN, R. A.; Navratil, J. A. (2004). Programmatic review of UNIDO/UNEP national cleaner production centres. Journal of Cleaner Production. 12(3), 195-205. 
MOORS, E.H.M.; Mulder, K.F.; Vergragt, K.F. (2005). Towards cleaner production: barriers and strategies in the base metals producing industry. Journal of Cleaner Production. 13(7), 657-668.

MULDER, K. (1998). Sustainable consumption and production of plastics? Technological Forecasting and Social Change, 58(I-2), I05-I 24.

PAILTHORP, R. (1977). Alternatives to End-of-Pipe treatment, Civil Engineering, 47(2), 49-52.

REPETTO, R. (1987). Economic incentives for Sustainable Production. The Annals of Regional Science, 2 I (3), 44-59.

ROBÈRT, K.-H; Schmidt-Bleek, B.; de Larderel, J.A.; Basile, G.; Jansen, J.L.; Kuehr, R.; Thomas, P.P.; Suzuki, M. Hawken, P.; Wackernagel, M. (2002). Strategic sustainable development - selection, design and synergies of applied tools. Journal of Cleaner Production. 10(3), | 97-2। 4 .

ROTHENBERG, S.; Pil, F. K.; Maxwell, J. (200I). Lean, Green and the quest for superior environmental performance. Production and Operations Management, 10(3).

SITARZ, D. (ed.) (1993) Agenda 21:The Earth summit strategy to save the planet. United States Boulder, Earth Press.

UNITED NATIONS (2005) Millennium Development Goals: Report 2005. Department of Public Information. United Nations. New York.

VELEVA, V.; Ellenbecker, M. (200I). Indicators of sustainable production: framework and methodology. Journal of Cleaner Production, 9(6), 519-549.

VELEVA, V.; Hart, M.; Greiner, T.; Crumbley, C. (200I) Indicators of Sustainable Production. Journal of Cleaner Production, 9(5), 447-452 